\title{
Estrogen Receptor Binding in the Oviduct Magnum of Guineafowl Hens: Comparison with White Leghorn Hens
}

\author{
Hiroshi Ogawa ${ }^{1}$, Hiroko Uchinashi ${ }^{2}$, Takehito Kuwayama ${ }^{2}$, Katuhide Tanaka ${ }^{2}$, \\ Tetsuya Takahashi ${ }^{3}$, Tadashi Yasuoka ${ }^{4}$ and Mitsuo Kawashima ${ }^{3}$ \\ ${ }^{1}$ Fuji Zootechnical Station, Tokyo University of Agriculture, Fujinomiya-shi, \\ Shizuoka 418-0109 \\ ${ }^{2}$ Department of Zootechnical Science, Tokyo University of Agriculture, \\ Atsugi-shi, Kanagawa 243-0034 \\ ${ }^{3}$ Department of Diversity and Resources, Gifu University, Yanagido, Gifu 501-1193 \\ ${ }^{4}$ Department of Oral and Maxillofacial Surgery, Gifu University School \\ of Medicine, Tsukasamachi, Gifu 500-8705
}

\begin{abstract}
Estrogen receptor bindings in cytosol and nuclear fractions of the magnum tissue of laying guineafowl and White Leghorn hens were examined by binding assays using $\left[{ }^{3} \mathrm{H}\right]$ -estradiol-17 $\beta$. The value of equilibrium dissociation constant $\left(\mathrm{K}_{\mathrm{d}}\right)$ in both the cytosol and the nuclear fractions was not different between the two different times, $1.5 \mathrm{~h}$ and 23 $\mathrm{h}$ after oviposition, and also between the guineafowl and the chicken. The maximum binding capacity $\left(\mathrm{B}_{\max }\right)$ was greater at $1.5 \mathrm{~h}$ after oviposition than at $23 \mathrm{~h}$ after oviposition in both cytosol and nuclear fractions of White Leghorn hens and in the nuclear fraction of the guineafowl hens, although the $B_{\max }$ value was smaller in the guineafowl hens than in White Leghorn hens. The results suggest that the smaller binding capacity of the estrogen receptor in the oviduct magnum may be related to the less amount of albumen secreted from the oviduct magnum in the guineafowl hens than in White Leghorn hens.

(Jpn. Poult. Sci., $37: 297-305,2000$ )
\end{abstract}

Key words : guineafowl, estrogen receptor, oviduct magnum, albumen secretion

\section{Introduction}

The magnum is the albumen-secreting portion of oviduct of birds (GILBERT, 1971). Tubular gland cells of the magnum synthesize ovoalbumin, a major component of egg white (WyBURN et al., 1970), by the action of estrogen through binding to its receptors existing in the cells (O'MALlEy et al., 1969). The amount of albumen in the egg of the guineafowl is less than that in the egg of the chicken (OGAwa et al., 2000). Responsiveness of the oviduct to estrogen for the weight increase is lower in the guineafowl than in the chicken (OGAwa et al., 1998). Whether the less amount of albumen secreted from the magnum of the guineafowl is due to the lower responsiveness to estrogen is obscure. In this study, experiments were performed to elucidate whether the binding property of the estrogen receptor in the magnum tissue of the oviduct is different between guineafowl and White Leghorn hens.

\section{Materials and Method}

Birds and tissues 
Guineafowl hens (2.3-2.9 kg BW, 25-42 weeks of age; Galor, France) and White Leghorn hens (1.4-1.8 kg BW, 25-42 weeks of age ; Super Nick) kept in individual cages under $14 \mathrm{~h}$ light (0400-1800 h) per day with feed and water given ad libitum consumption and laying 4-7 eggs in a sequence were used. In the first experiment, the guineafowl and the White Leghorn hens ( 3 birds each) were killed at $10: 00 \mathrm{~h}$ of a day of mid-sequence, and the magnum tissue of the oviduct was excised and used to examine binding properties of estrogen receptor. In the second experiment, the guineafowl and White Leghorn hens were killed at $1.5 \mathrm{~h} \mathrm{(6} \mathrm{birds} \mathrm{each)} \mathrm{and} 23 \mathrm{~h}$ ( 5 birds each) after oviposition of the initial egg of the sequence. After confirming the presence of ovum in the oviduct, the magnum tissue was excised and used for the determination of affinity and capacity of estrogen receptor.

\section{Chemicals and reagents}

Estradiol-17 $\beta\left(E_{2}\right)$, estrone $\left(E_{1}\right)$, estriol $\left(E_{3}\right)$, diethylstilbestrol (DES), testosterone $(T)$, progesterone $\left(\mathrm{P}_{4}\right)$ and corticosterone $(\mathrm{B})$ were purchased from Sigma Chemical Co. (St. Louis, MO, U.S.A.). $\quad\left[2,4,6,7,16,17-{ }^{3} \mathrm{H}(\mathrm{N})\right]-\mathrm{E}_{2}$ (Specific activity : $5218.11 \mathrm{GBq} / \mathrm{mmol}$ ) was purchased from E. I. Dupont de Nemours Co. Inc., (Boston, MA, U.S.A.). Bovine serum albumin (BSA) fraction $\mathrm{V}$, was obtained from Sigma Chemical Co., or Miles Inc. (Kankakee, IL, U.S.A.). All chemicals used were of analytical grade, obtained from Kanto Chemical Industries, Ltd. (Tokyo, Japan).

\section{Preparation of cytosol and nuclear fractions}

Cytosols (soluble fractions in hypotonic buffer solution) and nuclear fractions (insoluble fraction in the hypotonic buffer solution) of the oviduct magnum tissues were prepared using the same method as reported earlier (KAWASHIMA et al., 1984, 1987). After homogenizing in hypotonic Tris-EDTA-dithiothreitol-bacitracin buffer (TEDB ; $10 \mathrm{mM}$ Tris- $\mathrm{HCl}, 1.5 \mathrm{mM}$ EDT A, $1 \mathrm{mM}$ dithiothreitol, $0.5 \mathrm{mM}$ bacitracin, $\mathrm{pH}$ 7.4) containing $10 \%$ glycerol at $4^{\circ} \mathrm{C}$, the homogenates were centrifuged at $1,000 \times \mathrm{g}$ for $10 \mathrm{~min}$. The precipitated pellets were resuspended and recentrifuged. The supernatants were combined and treated for 30 min with dextran-coated charcoal pellets $(0.5 \%$ charcoal Norit $\mathrm{A}$ and $0.05 \%$ dextran $\mathrm{T} 70$ ) to remove endogenous steroids, and centrifuged at $105,000 \times \mathrm{g}$ for $1 \mathrm{~h}$. The supernatant was designated the cytosol fraction. The 1,000 $\times$ g sediments were washed once in Tris- $\mathrm{MgCl}_{2}$-dithiothreitol buffer (TMD ; $10 \mathrm{mM}$ Tris$\mathrm{HCl}, 1.5 \mathrm{mM} \mathrm{MgCl}_{2}, 1 \mathrm{mM}$ dithiothreitol, $\mathrm{pH} 7.4$ ) containing $0.25 \%$ Triton $\mathrm{X}-100$, and then washed twice in the TMD buffer. The washed pellets were suspended in the TMD buffer containing $2.4 \mathrm{M}$ sucrose and centrifuged for $1 \mathrm{~h}$. The resultant pellets were washed twice in TEDB buffer, suspended in 0.6 M KCl-TEDB buffer, and allowed to stand for $30 \mathrm{~min}$. The suspension was then centrifuged at $10,500 \times \mathrm{g}$ for $1 \mathrm{~h}$; the final supernatant was used as the nuclear fraction. The remaining pellets were measured for DNA. The cytosol and the nuclear fraction were immediately analyzed for the $\left[{ }^{3} \mathrm{H}\right]-\mathrm{E}_{2}$ binding.

Protein concentrations of the cytosol were determined by the method of LowRy et al. (1951) using BSA as a standard. DNA concentrations of the remaining pellets were determined by the method of BurTon (1956) using calf thymus DNA as a standard. 
Binding assays of the cytosol and the nuclear fractions were performed by the use of the same method of KawASHima et al. (1984). In the binding assays, $1.5 \mathrm{~m} l$ polypropylene microfuge tubes pretreated with TEDB buffer containing $2 \%$ BSA for $24 \mathrm{~h}$ at $4{ }^{\circ} \mathrm{C}$ were used. The cytosol ( $400 \mu \mathrm{g}$ protein $/ 200 \mu \mathrm{l}$ per tube) and the nuclear fractions (200 $\mu \mathrm{g}$ protein $/ 200 \mu \mathrm{l}$ per tube) were incubated at $4^{\circ} \mathrm{C}$ for $20 \mathrm{~h}$ with $\left[{ }^{3} \mathrm{H}\right]-\mathrm{E}_{2}(0.1$ to $3.2 \mathrm{nM})$ in the absence (total binding) or presence (nonspecific binding) of a 1,000 fold molar excess of unlabeled $\mathrm{E}_{2}$ in a total volume of $300 \mu \mathrm{l}$. The binding specificity was examined using 20, 200 and 2,000 $\mathrm{nM}$ of unlabeled $\mathrm{E}_{2}, \mathrm{E}_{1}, \mathrm{E}_{3}$, DES, and 20 and 2,000 $\mathrm{nM}$ of unlabeled $\mathrm{P}_{4}, \mathrm{~T}$ and $\mathrm{B}$ as competitors. After the incubation, bound and free steroids were separated by the use of a protamine sulfate precipitation method $(0.25 \mathrm{mg}$ protamine sulfate $/ 0.25 \mathrm{~m} l$ TEDB buffer per tube). The precipitated pellet was washed twice with $1 \mathrm{ml}$ of ice-cold TEDB buffer, and the scintillation fluid (Pico-fluor 40, Packard) was added. Radioactivity was measured by a liquid scintillation spectrometer (LSC-5100, Aloka). The counting efficiency for ${ }^{3} \mathrm{H}$ was $52-55 \%$. Specific binding was obtained by subtracting the nonspecific binding from the total binding and expressed as femtomoles ( $\mathrm{fmol}$ ) per milligram protein or fmol per milligram DNA. The equilibrium dissociation constant $\left(\mathrm{K}_{\mathrm{d}}\right)$ and the maximum binding capacity $\left(\mathrm{B}_{\max }\right)$ were determined by the method of ScATCHARD (1949).

\section{Statistical Analyses}

For comparison among means of more than two groups, the data were analyzed by one-way ANOVA (SNEDECOR and Cochran, 1989). When significant effects were found at $5 \%$ level, Duncan's new multiple range test was used to separate means (Duncan, 1955).

\section{Results}

\section{Relationship of specific $\left[{ }^{3} \mathrm{H}\right]$-estradiol- $17 \beta$ binding to concentration of protein}

Specific $\left[{ }^{3} \mathrm{H}\right]-\mathrm{E}_{2}$ binding increased linearly with the increase of the protein concentration from 50 to $800 \mu \mathrm{g}$ per tube in the cytosol and from 25 to $400 \mu \mathrm{g}$ per tube in the nuclear fraction in both the guineafowl and the chicken (Fig. 1.).

Time course of specific $\left[{ }^{3} \mathrm{H}\right]$-estradiol-17 $\beta$ binding during incubation

In the cytosol fractions of both the guineafowl and White Leghorn hens, the specific $\left[{ }^{3} \mathrm{H}\right]-\mathrm{E}_{2}$ binding increased during the first $4 \mathrm{~h}$, and maintained the maximal binding up to $24 \mathrm{~h}$. In the nuclear fractions, the specific $\left[{ }^{3} \mathrm{H}\right]-\mathrm{E}_{2}$ binding increased during the first $16 \mathrm{~h}$, and maintained the maximal binding up to $24 \mathrm{~h}$ (Fig. 2.).

Binding specificity

The specific $\left[{ }^{3} \mathrm{H}\right]-\mathrm{E}_{2}$ binding of cytosol and nuclear fractions was reduced by the presence of a 10 to 1,000 fold molar excess (20 to 2,000 nM) of unlabeled $E_{1}, E_{2}, E_{3}$ or DES, but not reduced by the presence of a 100 and 1,000 fold molar excess (200 and 2,000 nM) of unlabeled $\mathrm{B}, \mathrm{P}_{4}$ or $\mathrm{T}$ (Fig. 3.).

Saturation of specific $\left[{ }^{3} \mathrm{H}\right]$-estradiol-17 $\beta$ binding

Specific $\left[{ }^{3} \mathrm{H}\right]-\mathrm{E}_{2}$ binding of cytosol and nuclear fractions increased when increasing amounts of $\left[{ }^{3} \mathrm{H}\right]-\mathrm{E}_{2}$ were added, and was saturable at about $4 \mathrm{nM}$ (Fig. 4).

Scatchard analysis 
Guineafowl
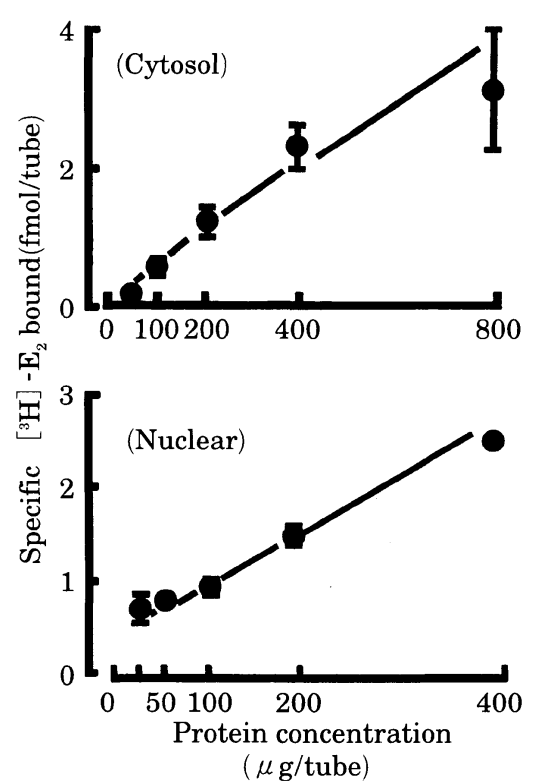

White Leghorn
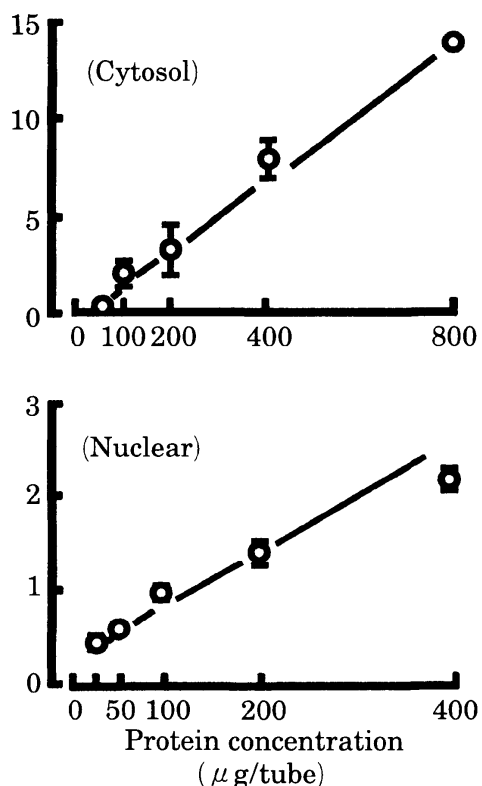

Fig. 1. Relationship of specific $\left[{ }^{3} \mathrm{H}\right]$-estradiol-17 $\beta\left(\left[{ }^{3} \mathrm{H}\right]-\mathrm{E}_{2}\right)$ binding to protein concentration in cytosol and nuclear fractions of the oviduct magnum of guineafowl and White Leghorn. Samples (Cytosol : 50-800 $\mu$ g protein per tube ; Nuclear : $25-400 \mu \mathrm{g}$ protein per tube) were incubated at $4^{\circ} \mathrm{C}$ for 20 hours with $2 \mathrm{nM}\left[{ }^{3} \mathrm{H}\right]-\mathrm{E}_{2}$ in the presence and absence of $2 \mu \mathrm{M}$ unlabeled $\mathrm{E}_{2}$. Each point represents the mean of triplicate determinations on three separate pooled samples, and the vertical bars represent SEM. When not shown, SEM falls in the symbol.

Scatchard analysis revealed a linear relationship between the amount of specific $\left[{ }^{3} \mathrm{H}\right]-\mathrm{E}_{2}$ binding and the ratio $\left(\mathrm{B}: \mathrm{F}\right.$ ) of specific $\left[{ }^{3} \mathrm{H}\right]-\mathrm{E}_{2}$ binding to free $\left[{ }^{3} \mathrm{H}\right]-\mathrm{E}_{2}$ (Fig. 4), indicating a single class of binding sites. The value of $\mathrm{K}_{\mathrm{d}}, \mathrm{B}_{\max }$, and correlation coefficient ( $\mathrm{r}$ ) between $\mathrm{B}: \mathrm{F}$ and specific $\left[{ }^{3} \mathrm{H}\right]-\mathrm{E}_{2}$ binding in the guineafowl was $0.38 \mathrm{nM}$ $\left(\mathrm{K}_{\mathrm{d}}\right), 4.28 \mathrm{fmol} / \mathrm{mg}$ protein $\left(\mathrm{B}_{\max }\right)$ and $-0.989(\mathrm{r})$ in the cytosol fraction, and $0.42 \mathrm{nM}\left(\mathrm{K}_{\mathrm{d}}\right)$, $0.35 \mathrm{fmol} / \mu \mathrm{g}$ DNA $\left(\mathrm{B}_{\max }\right)$ and $-0.985(\mathrm{r})$ in the nuclear fraction. The value of $\mathrm{K}_{\mathrm{d}}, \mathrm{B}_{\max }$, and correlation coefficient $(r)$ between $B: F$ and specific $\left[{ }^{3} \mathrm{H}\right]-\mathrm{E}_{2}$ binding in White Leghorn was $0.44 \mathrm{nM}\left(\mathrm{K}_{\mathrm{d}}\right), 5.25 \mathrm{fmol} / \mathrm{mg}$ protein $\left(\mathrm{B}_{\max }\right)$ and $-0.979(\mathrm{r})$ in the cytosol fraction, and $0.44 \mathrm{nM}\left(\mathrm{K}_{\mathrm{d}}\right), 0.21 \mathrm{fmol} / \mu \mathrm{g}$ DNA $\left(\mathrm{B}_{\max }\right)$ and $-0.962(\mathrm{r})$ in the nuclear fraction. Comparison of $K_{d}$ and $B_{\max }$ between guineafowl and chicken

The $K_{d}$ value in both the cytosol and the nuclear fractions was not different between the two different times, $1.5 \mathrm{~h}$ and $23 \mathrm{~h}$ after oviposition, and also between the guineafowl and the chicken (Table 1). The $B_{\max }$ value was greater at $1.5 \mathrm{~h}$ after oviposition than at $23 \mathrm{~h}$ after oviposition in both the cytosol and the nuclear fractions of the White Leghorn hens and in the nuclear fractions of the guineafowl hens (Table 2). The $B_{\max }$ value was smaller in the guineafowl hens than in the White Leghorn hens (Table 2). 


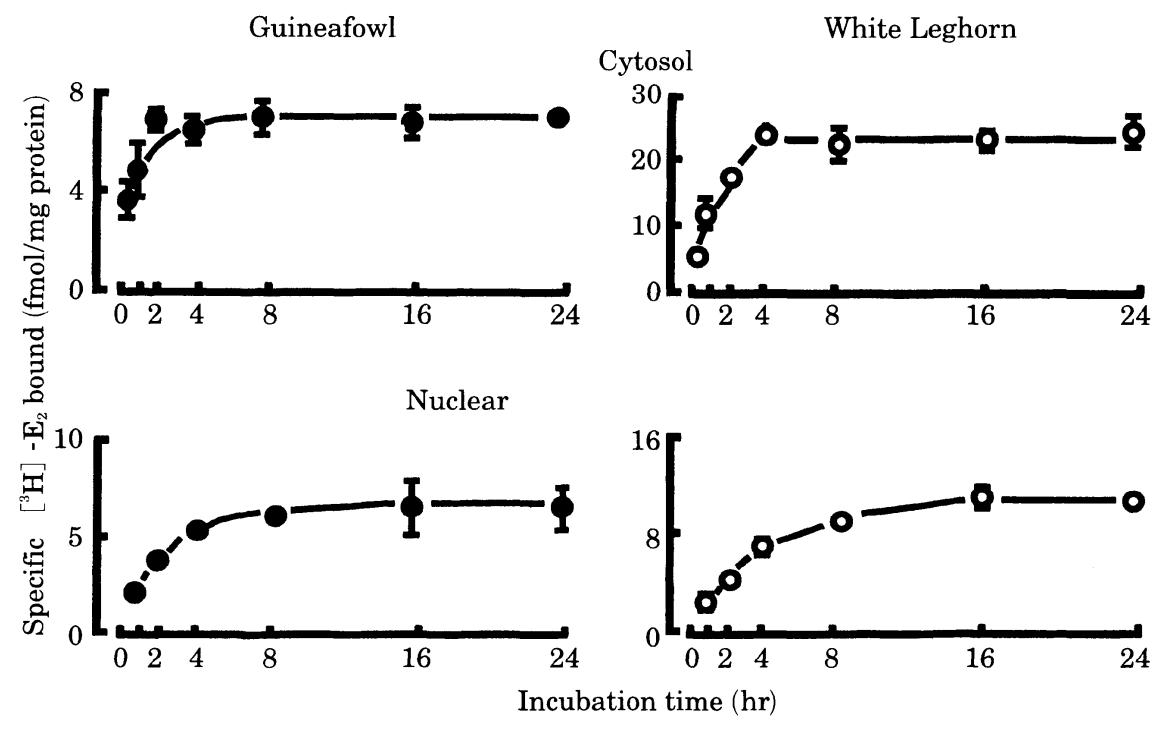

Fig. 2. Time course of specific $\left[{ }^{3} \mathrm{H}\right]$-estradiol- $17 \beta\left(\left[{ }^{3} \mathrm{H}\right]-\mathrm{E}_{2}\right)$ binding in cytosol and nuclear fractions of the oviduct magnum of guineafowl and White Leghorn. Samples (Cytosol: $400 \mu \mathrm{g}$ protein per tube ; Nuclear: $200 \mu \mathrm{g}$ protein per tube) were incubated at $4{ }^{\circ} \mathrm{C}$ for various times with $2 \mathrm{nM}\left[{ }^{3} \mathrm{H}\right]-\mathrm{E}_{2}$ in the presence and absence of $2 \mu \mathrm{M}$ unlabeled $\mathrm{E}_{2}$. Each point represents the mean of triplicate determinations on three separate pooled samples, and the vertical bars represent SEM. When not shown, SEM falls in the symbol.

\section{Discussion}

The presence of estrogen receptor in cytosol and nuclear fractions of the magnum tissue of the oviduct was demonstrated in guineafowl hens as well as in White Leghorn hens by the use of radioligand binding assays for the binding property of a receptor such as binding specificity (Fig. 3), saturation (Fig. 2 and Fig. 4), affinity (Fig. 4) and capacity (Fig. 4).

The affinity of the estrogen receptor in the cytosol and nuclear fractions as indicated by the value of the equilibrium dissociation constant, was found to be not different between the birds of the different species, the guineafowl and the chicken (Table 1). The affinity was very similar to that of estrogen receptor reported on the hypothalamus and the pituitary (KAWASHIMA et al., 1987) of the chicken.

The $B_{\max }$ value of the estrogen receptor in both cytosol and nuclear fractions of White Leghorn hens was greater at $1.5 \mathrm{~h}$ after oviposition than at $23 \mathrm{~h}$ after oviposition (Table 2). In the guineafowl, the $B_{\max }$ value in the nuclear fraction was greater at $1.5 \mathrm{~h}$ after oviposition than at $23 \mathrm{~h}$ after oviposition (Table 2). The difference in the $\mathrm{B}_{\max }$ values of the cytosol fraction was not statistically significant $(P>0.05)$. However, the $\mathrm{B}_{\max }$ value in the cytosol fraction was slightly greater at $1.5 \mathrm{~h}$ after oviposition than at $23 \mathrm{~h}$ after oviposition. The time, $1.5 \mathrm{~h}$ after oviposition is the time of albumen formation in the magnum, and the time, $23 \mathrm{~h}$ after oviposition, is the time of no albumen 
Guineafowl
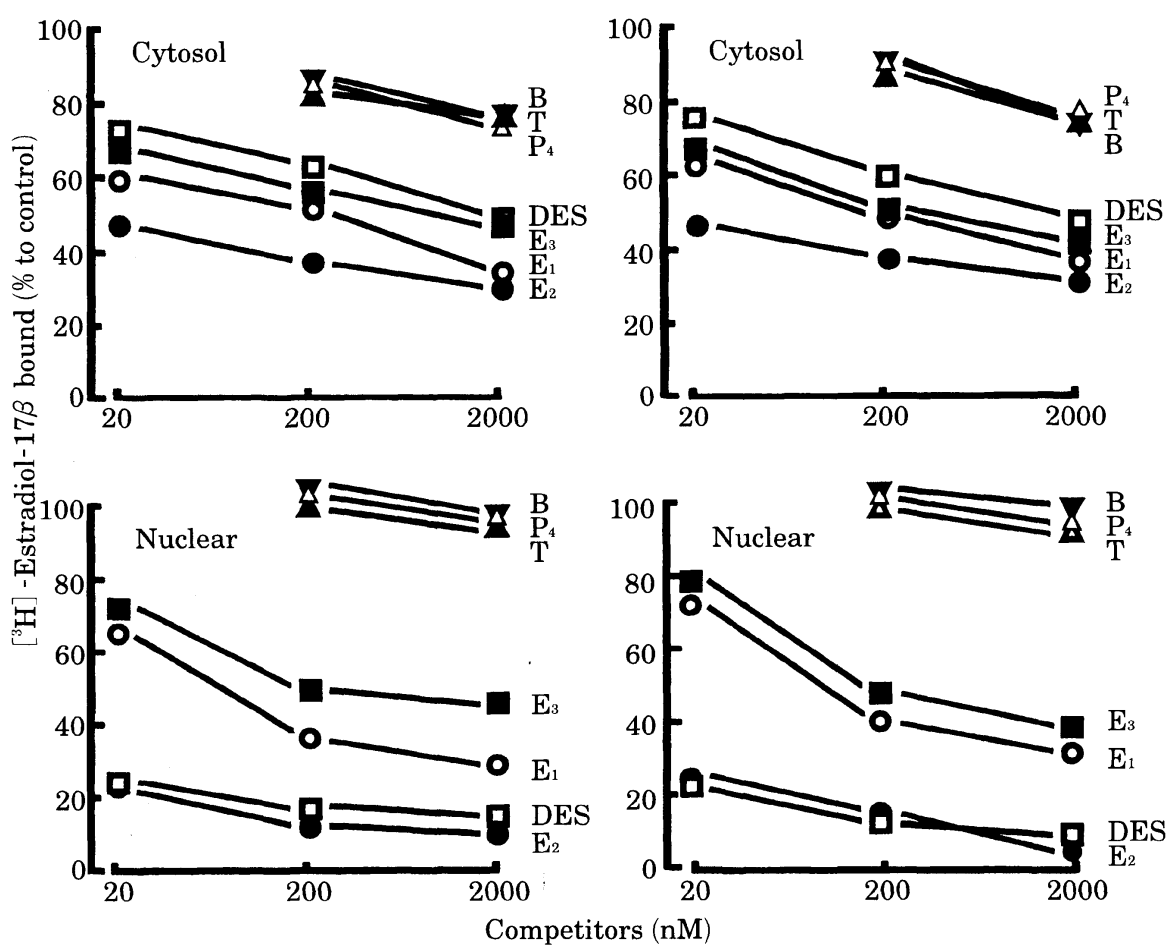

Fig. 3. Competition for $\left[{ }^{3} \mathrm{H}\right]$-estradiol- $17 \beta\left(\left[{ }^{3} \mathrm{H}\right]-\mathrm{E}_{2}\right)$ binding in the cytosol and nuclear fractions of the oviduct magnum of the guineafowl and White Leghorn. Samples (Cytosol: $400 \mu \mathrm{g}$ protein/tube ; Nuclear: $200 \mu \mathrm{g}$ protein/tube) were incubated at $4^{\circ} \mathrm{C}$ for with $2 \mathrm{nM}\left[{ }^{3} \mathrm{H}\right]-\mathrm{E}_{2}$ in the absence (control) or presence of various fold molar excess of unlabeled competitions, and the $\left[{ }^{3} \mathrm{H}\right]-\mathrm{E}_{2}$ binding was measured. The value of $\left[{ }^{3} \mathrm{H}\right]-\mathrm{E}_{2}$ binding in the control was $33.18 \mathrm{fmol} / \mathrm{mg}$ protein (Cytosol) and $8.94 \mathrm{fmol} /$ $\mathrm{mg}$ protein (Nuclear) in the guineafowl, and $30.27 \mathrm{fmol} / \mathrm{mg}$ protein (cytosol) and $10.14 \mathrm{fmol} / \mathrm{mg}$ protein (Nuclear) in White Leghorn hens, respectively. Each point represents the mean of triplicate determinations of two separate pooled samples. The competitors tested were : estradiol-17 $\beta\left(\mathrm{E}_{2}\right.$ : O), estrone $\left(\mathrm{E}_{1}: \bigcirc\right)$, estriol $\left(\mathrm{E}_{3}: \mathbf{\square}\right)$, diethylstilbestrol (DES : $\square$ ), testserone $(\mathrm{T}: \boldsymbol{\Delta})$, progesterone $\left(\mathrm{P}_{4}: \triangle\right)$ and corticosterone $(\mathrm{B}: \boldsymbol{\nabla})$.

formation (GILBERT, 1971). Therefore, this finding suggests that the binding capacity of estrogen receptor may be related to the albumen formation in the magnum of the oviduct.

The mechanism of the action of estrogen in cells of the oviduct of the chicken in stimulating the biosynthesis of egg-white proteins has been well established (O'MALLEY et al., 1969). The finding that the capacity of the estrogen receptor in the magnum, the albumen secreting portion of the oviduct, was less in the guineafowl than in the chicken (Table 2) suggests that the less capacity may be related to the less amount of albumen in guineafowl eggs than in White Leghorn eggs (OGAW et al., 2000), and may be also related to the lower responsiveness to estrogen for the increase in the weight of 

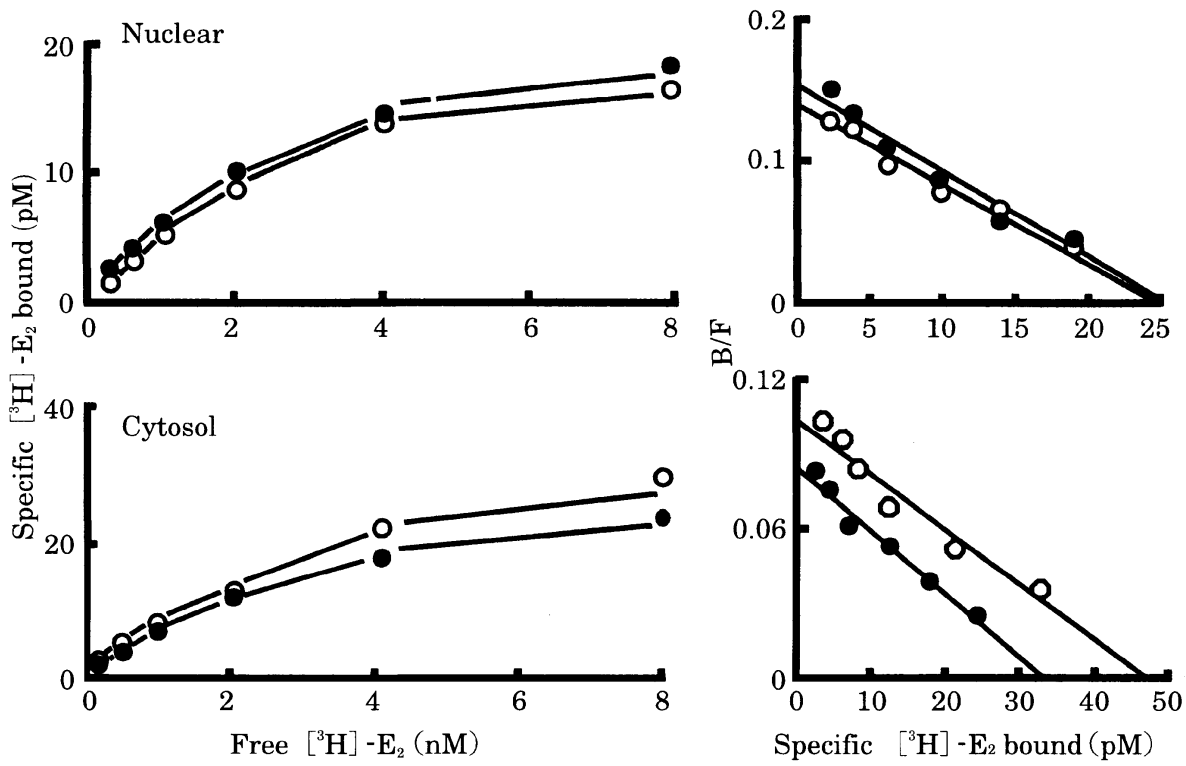

Fig. 4. Specific bindings of $\left[{ }^{3} \mathrm{H}\right]$-estradiol-17 $\beta\left(\left[{ }^{3} \mathrm{H}\right]-\mathrm{E}_{2}\right)$ in cytosol and nuclear fractions of the oviduct magnum of the laying guineafowl ( ) and White Leghorn hens $(O)$ without regard to the time of a laying sequence (Left), and their Scatchard plot (Right). Samples (Cytosol : $400 \mu \mathrm{g}$ protein per tube ; Nuclear : $200 \mu \mathrm{g}$ protein per tube) were incubated at $4^{\circ} \mathrm{C}$ and 20 hours with variouos concentrations $(0.25$ to $8 \mathrm{nM})$ of $\left[{ }^{3} \mathrm{H}\right]-\mathrm{E}_{2}$ in the absence or presence of a 100 -fold molar excess of unlabeled $\mathrm{E}_{2}$. Each point represents the mean of duplicate determinations of one pooled sample.

Table 1. The equilibrium dissociation constant of estrogen receptor in the magnum tissue of the guinea fowl (GF) and the chicken (WL)

\begin{tabular}{ccccccc}
\hline \hline $\begin{array}{c}\text { Hrs after } \\
\text { oviposition }\end{array}$ & Bird & $\begin{array}{c}\text { No. of } \\
\text { birds }\end{array}$ & $\begin{array}{c}\text { Cytosol } \\
\text { (nM) }\end{array}$ & \multicolumn{2}{c}{$\begin{array}{c}\text { Nuclear } \\
\text { (nM) }\end{array}$} & \\
\hline \multirow{2}{*}{1.5} & GF & 6 & $0.38 \pm 0.03^{\#}$ & $\mathrm{a}^{\# \#}$ & $0.35 \pm 0.01^{\#}$ & $\mathrm{~A}^{\# \#}$ \\
& $\mathrm{WL}$ & 6 & $0.45 \pm 0.03$ & $\mathrm{a}$ & $0.36 \pm 0.02$ & $\mathrm{~A}$ \\
\multirow{2}{*}{23} & $\mathrm{GF}$ & 5 & $0.38 \pm 0.02$ & $\mathrm{a}$ & $0.37 \pm 0.03$ & $\mathrm{~A}$ \\
& $\mathrm{WL}$ & 5 & $0.46 \pm 0.04$ & $\mathrm{a}$ & $0.40 \pm 0.03$ & $\mathrm{~A}$ \\
\hline
\end{tabular}

* Mean \pm SEM

\#\# Means in the same column with same letter are not significantly different by

Duncan's new multiple range test $(\mathrm{P}<0.05)$.

whole oviduct in guineafowl than in White Leghorn chickens (OGawa et al., 1998).

\section{Acknowledgments}

This study was supported by the Grant-in-Aid for Scientific Research (C) from Japan Society for the Promotion of Science (No. 12660249). 
Table 2. The maximum binding capacity of estrogen receptor in the magnum tissue of the guinea fowl (GF) and the chicken (WL)

\begin{tabular}{|c|c|c|c|c|c|c|}
\hline \multirow{3}{*}{$\begin{array}{c}\begin{array}{c}\text { Hrs after } \\
\text { oviposition }\end{array} \\
1.5\end{array}$} & \multirow{2}{*}{$\frac{\text { Bird }}{\text { GF }}$} & \multirow{2}{*}{$\begin{array}{c}\begin{array}{c}\text { No. of } \\
\text { birds }\end{array} \\
6\end{array}$} & \multicolumn{2}{|c|}{$\begin{array}{c}\text { Cytosol } \\
\text { (fmol/mg protein) }\end{array}$} & \multicolumn{2}{|c|}{$\begin{array}{c}\text { Nuclear } \\
\text { (fmol/ } / \text { gDNA) }\end{array}$} \\
\hline & & & $6.15 \pm 0.13^{\#}$ & $c^{\# \#}$ & $0.57 \pm 0.00^{\#}$ & $\mathrm{C}^{\# \#}$ \\
\hline & WL & 6 & $8.67 \pm 0.22$ & $\mathrm{a}$ & $0.67 \pm 0.01$ & A \\
\hline \multirow[b]{2}{*}{23} & GF & 5 & $5.67 \pm 0.17$ & $\mathrm{c}$ & $0.53 \pm 0.01$ & $\mathrm{D}$ \\
\hline & WL & 5 & $7.83 \pm 0.15$ & $\mathrm{~b}$ & $0.62 \pm 0.02$ & $\mathrm{~B}$ \\
\hline
\end{tabular}

${ }^{*}$ Mean \pm SEM

${ }^{\# *}$ Means in the same column with same letter are not significantly different by Duncan's new multiple range test $(\mathrm{P}<0.05)$.

\section{References}

Burton, K. (1956) A study of the condition and mechanism of the diphenylamine reaction for the colorimetric estimation of deoxyribonucleic acid. Biochemical Journal, 62 : 315-323.

Duncan, D.B. (1955) Multiple range and multiple F tests. Biometrics, $11: 1-42$.

Gilbert, A.B. (1971) Egg albumen and its formation. In 'Physiology and Biochemistry of the Domestic Fowl (Bell, D.J. and Freeman, B.M. eds.' Nol. 3. pp. 1291-1329. Academic Press, London \& New York.

Kawashima, M., Sakae, A., Kamiyoshi, M. and Tanaka, K. (1984) Properties of cytoplasmic and nuclear estrogen receptors in the hen oviduct uterus (shell gland). Japanese Journal of Zootechnical Science, 55 (9) : 635-642. (in Japanese)

Kawashima, M., Kamiyoshi, M. and Tanaka, K. (1987) Presence of estrogen receptors in the hen hypothalamus and pituitary. Endocrinology, $120: 582-588$.

Lowry, O., Rosebrough, N.J., FArr, A.L. and Randall, R.J. (1951) Protein measurement with the folin phenol reagent. Journal of Biological Chemistry, $193: 265-275$.

Ogawa, H., Kuwayama, T. and TAnAKA, K. (1998) Early growth of oviduct, changes in plasma estradiol-17 $\beta$ concentration and response to estrogen for weight increase of oviduct in the guinea fowl and White Leghorn chickens. Japanese Poultry Science, 35 (2) : 125-131. (in Japanese)

Ogawa, H., Kuwayama, T., Uehara, M., Kawakami, S., Sakaguchi, E. and Tanaka, K. (2000) Characteristics of the guineafowl egg. Japanese Poultry Science, 37 (1) : 40-42. (in Japanese)

O’Malley, B.W., McGuire, W.L., Kohler, P.O. and Korenmann, S.G. (1969) Studies on the mechanism of steroid hormone regulation of synthesis of specific proteins. Recent Progress in Hormone Research, $25:$ 105-160.

SCATCHARD, G. (1949) The attractions of proteins for small molecules and ions. Annals of the New York Academy of Science, $51:$ 660-672.

SNedecor, G.W. and Cochran, W.G. (1989) One-way classifications. Analysis of variance. In 'Statistical Methods $8^{\text {th }}$ ed. (Snedecor, G.W. and Chochran, W.G., eds.)' pp. 217-236, Iowa State University Press, Ams, IA, U.S.A.

Wyburn, G.M., Johnston, H.S., Draper, M.H. and Davidson, M.F. (1970) The fine structure of the infundibulum and magnum of the oviduct of Gallus domesticus. Quarterly Journal of Experimental Physiology, 55 : 213-232. 
ホロホロチョウの卵管膨大部におけるエストロジェンレセプター の結合性 : 白色レグホーン種のニワトリとの比較

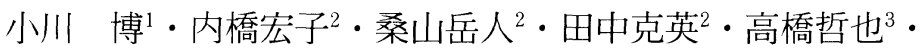

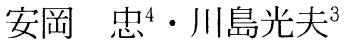 \\ 1 東京農業大学富士畜産農場, 富士宮市 418-0109 \\ 2 東京農業大学農学部畜産学科, 厚木市 $243-0034$ \\ 3 岐皁大学農学部生物資源生産学科, 岐皁市柳戸 501-1193 \\ ${ }^{4}$ 岐皁大学医学部口腔外科学講座, 岐阜市柳戸 500-8705
}

産卵期のホロホロチョウと白色レグホーン種のニワト リについて，卵白分泌時と非分泌時の卵管膨大部組織の サイトゾール画分及び核画分におけるェストロジェンレ セプターの平衡解離定数 $\left(\mathrm{K}_{\mathrm{d}}\right)$ と最大結合容量 $\left(\mathrm{B}_{\max }\right)$ を $\left[{ }^{3} \mathrm{H}\right]$-estradiol-17 $\beta$ を使用した結合アッセイによって 求めた。

$K_{d}$ 値はサイトゾール画分及び核画分のいずれにおい ても卵白分泌時之非分泌時との間及びホロホロチョウと ニワトリとの間に差違は認奶らなかった。 $\mathrm{B}_{\max }$ は, 二 ワトリのサイトゾール画分及び核画分，ホロホロチョウ
の核画分においては卵白分泌時の方が非分泌時よりも大 であった。また，ホロホロチョウの方が二ワトリよりも 小さかった。それ故, ホロホロチョウの卵の卵白量が少 ないことは，卵管膨大部のエストロジェンレセプターの 結合容量が少ないことに起因するのであろうと思われ る。

(家禽会誌，37：297-305，2000） キーワード：ホロホロチョウ，エストロジェンレセプ 夕一, 卵管膨大部, 卵白分泌 